\title{
MUSEUMS AND SITES OF PERSUASION
}

Politics, Memory and Human Rights

Edited by Joyce Apsel and Amy Sodaro

First published 2020

ISBN: 978-1-138-56535-7 (hbk)

ISBN: 978-1-138-56781-8 (pbk)

ISBN: 978-1-138-56782-5 (ebk)

\section{3 \\ CURATING ENSLAVEMENT AND THE COLONIAL HISTORY OF DENMARK}

The 2017 centennial

Astrid Nonbo Andersen

(CC BY-NC-ND 4.0)

The OA chapter is funded by University of Hull 


\title{
3 \\ CURATING ENSLAVEMENT AND THE COLONIAL HISTORY OF DENMARK
}

\section{The 2017 centennial $^{1}$}

\author{
Astrid Nonbo Andersen
}

March 31, 2017 marked the centennial of the transfer ${ }^{2}$ of the Danish West Indies (DWI) to the United States, since then known as the US Virgin Islands (USVI). The centennial resulted in nearly 30 special exhibitions around the country on various aspects of the history of the Danish West Indies (DWI). ${ }^{3}$ The history of enslavement and colonialism is global; their legacies have produced a range of different effects around the world, engaging a global audience in discussions on how to properly memorialize this past and present its ongoing impact. This chapter explores how curators at Danish museums involved in the centennial commemoration responded to challenges both from engaged audiences often directly touched by repercussions of colonialism and enslavement, as well as their efforts to persuade an ethnic Danish audience with little or no prior knowledge of the DWI to adopt new understandings of the colonial past and present.

As noted in this volume's Introduction and elsewhere, Holocaust memorial culture has come to play referential roles in other commemorative contexts, tacitly serving as a guide for how to introduce mass violence. This type of commemoration often combines two parallel approaches: on the one hand, to document and expose the nature and scale of violence-logos - and on the other, to create identification and empathy with victims - pathos. Both strategies are fundamental to sites of persuasion in their work to change the attitudes and behaviors of their visitors.

When translated into the context of enslavement, however, these two strategies raise new questions. Erica Lehrer and Cynthia E. Milton pose a critical question that many museums and sites of persuasion must address: how "to bear witness, to give space to absent people, objects and cultures, to present violent conflict without perpetuating its logic?" (2011, 4). Translated into the Danish context, the question becomes: how can exhibits deal with the painful history of 
slavery and colonialism in a way that bridges divides, creates empathy, and shapes attitudes and ethics, without perpetuating the representation of people of African descent as dehumanized commodities? This was among the questions relevant for many museums wanting to challenge dominant national narratives in Denmark. Hence, this chapter explores the curatorial deliberations behind the special exhibitions on the DWI, focusing on three of the largest, which all worked to identify a connection between past and present. However, interviews with curators of other centennial exhibitions also inform my discussion. I collected this data through formal semi-structured interviews and informal talks with 26 curators, and visits to 19 exhibitions.

\section{The background}

When the treaty of sale was ratified on August 4, 1916, the decision to let go of the DWI sparked intense debate in Denmark, but interest dwindled after the islands were transferred to the US on March 31, 1917. Nevertheless, cultural remnants lingered in a nostalgic narrative of an innocent colonialism dominated by a melancholic longing after a tropical paradise lost, ignoring the mass violence of slavery and taking cues from patronizing ideas of a benevolent civilizing mission in Greenland (Andersen 2013a, 2013b; Andersen \& Thisted forthcoming). Even before 1917, Danish historians relegated African-Caribbean experiences to the narrative margins (Andersen 2014). As mentioned in the Introduction to this book (p. 4-5), the end of the Cold War contributed to a memory boom that provided space for a new human rights discourse in the 1990s, as well as a new reparations politics (Barkan 2000). Since the late 1990s, politicians and NGOs from the USVI have demanded reparations from Denmark, but every Danish government, regardless of political orientation, has turned the demand down. However, the demand coincided with renewed interest in the DWI, particularly among Danish scholars inspired by postcolonial and subaltern studies. Taken together, these currents have created a growing historic awareness of Danish colonial history over the past 20 years, culminating in 2017 with the centennial (Andersen 2013a, 2017, 2018).

Reflecting and contributing to a more general lack of public knowledge about this aspect of Denmark's history, the history of enslavement in the DWI was not part of any permanent museum exhibition in Denmark before 2001. The Royal Library, the National Museum, and the Danish West Indian Society occasionally organized special exhibitions on the DWI (Olwig 2003), but the majority largely omitted the violence of enslavement and racism. For example, the exhibition at the Danish National Museum marking the 50th anniversary of Transfer Day in 1967, entitled West Indian Living Rooms, mainly displayed mahogany furniture historically belonging to the white plantation elites in the DWI (Andersen 2017).

In 2001, the Danish National Museum opened its permanent exhibition, Histories of Denmark 1660-2000, which dedicated one room to the history of 
Danish colonies in the Caribbean, West Africa, and India under the heading "World Trade and Colonies." This was the first time slavery was included in a permanent museum exhibition in Denmark. One exhibition box documents the cruelty of slavery in a historical, unemotional way, relying upon logos. The cruelty of enslavement is not hidden here, but while the overarching ambition of the exhibit is to show a plurality of perspectives on modern Danish historyincluding those of lower classes and immigrants - the same plurality does not characterize this room, which mainly presents colonial history from an elite experience with a focus on trade companies.

An identical approach also dominates the exhibition Tea Time-the First Globalization at the Maritime Museum of Denmark in Elsinore, produced in 2013. This exhibition makes less use of the kinds of affective strategies that are used in the rest of the museum. In Tea Time, large exhibition boxes containing historical objects serve as geographical markers representing Denmark's former colonies, trading posts, and overseas trade with China. Each box is decorated with one of the most important goods from the location in question. The box representing the African Gold Coast features plastic black hands and feet arranged in a tight grid, articulating bodies as they were packed into ships, and thus showing Africans as commodities. Throughout this exhibit visitors are encouraged to play a trading game, which effectively turns them into merchants. Since it opened, the exhibition has been criticized for dismissing social history, limiting agency to white elites and reducing colonialism to a matter of trade (Halberg 2016; Nielsen 2017).

Ongoing criticisms influenced by the contemporary museological perspective that works to incorporate social and cultural history, bringing in diverse voices that were previously silenced (see Introduction) contributed to the National Museum's decision in 2010 to take a new look at the DWI. The museum began to prepare a large special exhibition, The West Indians, that would open in conjunction with the centennial. The exhibition planned to incorporate recent research on the Danish West Indies inspired by subaltern studies and a historyfrom-the-margins approach, to give voice to the enslaved people and the colonized. This material was not entirely new for the National Museum, which had addressed different aspects of the slave trade and the DWI in two smaller special exhibitions shown in 2010 and 2011. The first focused on archeological excavations of the plantation Frederiksgave in Ghana, dealing with the contested history that the slave trade presents in Ghana today (Brichet 2017), ${ }^{4}$ and the second explored the first 150 years of the history of the DWI, including various aspects of the life of enslaved Africans. ${ }^{5}$ But the exhibition planned for the centennial was intended to be much larger and more prominent.

Accordingly, there was public outrage both in Denmark and museum circles in Europe when the director of the National Museum announced that the museum was forced to cancel the special exhibition after a general budget cut to state museums in 2015. While seemingly a significant setback to addressing the difficult past of slavery and colonialism, the cancellation prompted many smaller museums-including ad hoc museum activities outside of the established 
museums - to take on the subject, often in frustration with the cancellation. On a practical level, this meant that the timeframe of most museums was short, with the centennial looming in just two years' time impacting the scope of projects developed. At the same time, it also made it possible for smaller museums to borrow objects from the large colonial collections at the National Museum-a window of opportunity that closed again when the National Museum later decided to go through with a smaller permanent exhibition on the topic, Voices from the Colonies, which opened in October 2017.

\section{Public debate in the run-up to transfer day}

The editors of this volume argue that state-sponsored institutions often reinforce dominant state narratives, because of political, economic, and social pressures, whereas local institutions are often less likely to take up official hegemonic narratives (p. 3). However, this dynamic does not seem to completely hold in Denmark's case. Most museums involved in the 2017 centennial exhibitions receive public funding either directly from the state or through local municipalities. Some received additional funding from special funds allocated by the Danish Parliament in response to the cancellation at the National Museum.

Since the 1960s, Danish state cultural policies have been guided by the principle that politicians should refrain from micromanagement of cultural institutions, known as the "arm's-length principle." The principle has been under persistent pressure in recent years but seems to have held, with some exceptions which I will return to; most curators indicated that they felt no pressure to conform to a dominant state or government narrative. A smaller group already aligned with dominant narratives: that of an "innocent" colonialism (Andersen 2013a, 2017) or-more often-narratives similar to what Edward Linenthal calls a "comfortable horrible memory," which does nothing more than confirm what we already think and feel $(1995,267)$. These museums briefly addressed slavery as cruel, but with no ambition to discuss the legacies of either enslavement or colonialism. However, another group of curators indicated that their exhibitions were planned to challenge what they saw as the ongoing consequences of slavery and colonialism both in Denmark and abroad, such as racism, anti-immigration policies, and global injustice. These curatorial choices did not reflect a divide between larger state institutions and smaller private or local museums, but rather the profile of each museum and choices of individual curators.

The centennial sparked protracted discussions and debates about the past and its aftereffects. These debates took place both in the media and in the many seminars, workshops, and public talks held in the years and months prior to March 31, 2017, including several seminars on colonial curatorial challenges and

museum practice. ${ }^{6}$ These museological seminars seemed to be particularly influential for those curators who attended, as is evidenced in many of the dilemmas, choices, and solutions that they grappled with. Furthering the curatorial challenges, the public debates were split along different political lines: one inspired 
by right-wing populism and another by critical discourses, particularly decolonial critiques, postcolonial studies, and black feminism.

In the summer of 2016, the National Gallery announced that it had removed words such as "neger" ("Negro") and "hottentot" from its registers of work titles - not original titles of artworks, but titles that had been assigned over time. Conservatives and popular right-wing politicians protested loudly against this "political correctness," arguing that many older Danes still consider the term "neger" a neutral term. ${ }^{7}$ Similarly, Museum Vestsjælland in Holbæk-before its exhibition Vestindien/Vestsjalland (West Indies/Western Sjalland) opened-was criticized intensely by the political right, which believed the museum had removed from display a little group of black dolls, thus giving in to what were called "politically correct" sensitivities. The controversy was in fact built on a misunderstanding and the museum kept to its original plan: exhibiting the dolls to invite the audience to reflect on whether the dolls and the word "Negerdukke" ("Negro doll") often used to denote these dolls was racist. ${ }^{8}$

The criticism from the right was stressful for the museum staff to experience but had uneven effects on how other museums prepared for 2017. One curator at a larger museum noted that museums that wanted to challenge the dominant narratives had to prepare themselves for these kinds of crises "and for demands from right-winged, influential and democratically well-supported political parties that funding will be reduced for museums that act politically correct." Hence, some institutions found it necessary to set up a damage control strategy to handle the political pressure and were reluctant to use provocative issues in promoting their exhibitions in the press. Other curators with a critical approach stated that they did not feel such constraints in the curatorial process and seemed little concerned with the political pressure. This difference suggests that the arm's-length principle is indeed under pressure, but seemingly intact to the degree that museum directors and curators still react unevenly to it - and that some museums with a critical approach chose to fly under the media radar.

A different strand of debate and critique came from a range of interested groups including artists, students, academics, curators, activists working with refugees, civil society organizations problematizing transnational adoption, writers, and publishers. Some were Virgin Islanders or belonged to the African or African-Caribbean diaspora in Denmark, others not. Common to most was a focus on the present-day consequences of colonialism such as racism, racialization, capitalist globalization, and global injustice. Some were less occupied with the colonial past itself but took the lack of general awareness about it as a starting point for their critique of ongoing repercussions in Denmark and abroad. Others emphasized previous representations of the colonial past, focusing on the lack of voice of the enslaved and colonized subjects.

The museum as an institution is deeply embedded in the history of colonialism. The troubled history of the collection, uprooting, and display of exoticized artifacts - and people-inescapably reverberates today. Hence, the museum context in and of itself is deeply disturbing to many descendants of 
colonized peoples. Moreover, the prevalence given to existing objects and written documents - if not interpreted through a lens inspired by a subaltern or history-from-the-margins approach-tends to silence the voice of those enslaved and colonized, who often did not produce texts and whose objects were stolen or destroyed (Barringer \& Flynn 1998; Kaplan \& Oldfield 2010; Karp et al. 2006). Consequently, the curators faced a number of representational and ethical dilemmas like those Ross Wilson (2011) identifies as the curatorial complex.

There were curators who had been inspired by history-from-the-margins, subaltern, postcolonial, and, to a lesser degree, decolonial approaches. However, this group was sometimes challenged by criticism from decolonial activists, which they found particularly frustrating. One formulated it this way: "There's this demand that you deal with race, but at the same time you should, as a white person, expect to be thrashed when doing it." The fear of being accused of merely reproducing racist institutional approaches even when actively attempting to counter them was pronounced. Curators reacted differently to these types of provocations. Some saw the public debate-right- or left-leaning and however intense-as a sign of success that they had been able to engage a wider audience. Some described the curatorial process as a steep learning curve. As one stated: "I think we made a fine exhibition, but with the knowledge I have now, I probably would have started somewhere else." Others experienced the multisided critique as highly stressful, or as one expressed it: "As if dealing with death threats from maniac right-wings isn't bad enough." Some found that the experience had been so stressful that they were not sure they would take on similar subjects again. Others found that although some provocations had been unfair and transgressive, the critique in general had made them reconsider their curatorial practice. The Workers Museum even embraced it publicly, when-one month before the exhibition closed-the museum invited academics, activists, and artists to intervene in the exhibition and correct phrases directly onto the exhibition texts with red ink, corrections which then became part of the display. ${ }^{9}$

\section{Challenging a distanced audience}

Sensitizing a primarily ethnic Danish audience that is not descended from enslaved Africans to the lingering effects of colonialism and slavery was a central goal of several special exhibitions. Some curators explained to me that connecting past and present was the raison d'être of all their exhibitions. Others indicated that in this case, because the consequences of slavery and colonization are often unknown to the Danish audience, they had a special obligation to expose them. A limited number of museums openly aimed at addressing consumer habits of the visitors both to highlight and fight present-day slavery.

Explorations of the consequences of slavery and colonialism differed between exhibits. Some museums addressed issues like contemporary forms of slavery and 
exploitation of workers, environmental damages, neocolonialism, racism and racial stereotypes, and socioeconomic inequality-both in the USVI and globally. Other themes included citizenship, national identity, and a biased perspective on or lack of sensitivity to the past. Yet another approach was to leave the questions unanswered, encouraging the visitor to reflect on these dilemmas for themselves.

All state-funded Danish museums have specific audiences they are obligated to reach as part of their public responsibilities. However, many curators agreed that their target audience in the context of the centennial was largely a Danish audience with no or only little prior knowledge of colonial history, or a prior interest influenced by ideas of a gentler colonialism or nostalgia. Based on my interviews, most curators agreed that the task of the museum is to catch the attention of the audience with something they might know, challenge this knowledge, and bring the audience to a new - and perhaps unexpected - understanding of the topic. However, curators differed on how explicitly a museum should try to persuade the visitor to embrace a message, echoing Rancière's notion of the "emancipated spectator" (2009).

In an interview conducted for an earlier research project, one museum curator argued that the typical Danish audience tends to resist directly imposed messages - especially if moralizing or overtly emotional. This observation might be correct, but to date there are no comparative studies that verify the claim that Danish audiences react in a more emotionally distanced way than museum visitors of other nationalities. A large audience segmentation study by the Government Agency of Culture (Kulturarvsstyrelsen) from 2010 showed that the typical museum visitor was a middle-class, well-educated, liberal, middle-aged woman, usually living in the capital area. According to the evidence, older men frequent museums more than both younger men and women; women prefer art exhibitions and men natural history, while the visitor profile of cultural history museums is gender neutral. ${ }^{10}$ This data could indicate a predominance of visitors viewing history as neutral and objective, which would mirror the typical school education of older generations, and translate into their being more comfortable with exhibitions guided more by logos than pathos. However, this pattern probably reflects age, class, and political orientation more than a particular "Danish" sentiment.

The very emotional approach to colonial history found among many descendants of enslaved Africans in the Caribbean is unquestionably rare among most Danes. This has to do with the fact that this history was, until recently, ignored in Denmark. It also reflects how family history and personal experiences of the visitor often influence his/her emotional response to the exhibition in question. Danes generally have a more emotional attachment to other parts of their history. For example, the German occupation of Denmark during 1940-45 or the lost war against Prussia-Austria in 1864 (which led to high losses of life among Danish commoners, economic ruin, and huge territorial losses only partly regained in 1920) both play major roles in Danish national memory cultures. 
They never fail to stir high emotions if dominant narratives are questioned, as these pasts link intrinsically to the formation of the modern Danish nation-state and reside in many family narratives. In comparison, the history of the Danish West Indies is often considered marginal to the history of the Danish nationstate, and while it does reside in a limited number of Danish family narratives, these are much less common than those of 1864 or 1940-45 (Andersen 2013a, 2014).

Curious about the observation by the above-mentioned curator about the "coolness" of Danish audiences, I subsequently asked all curators interviewed for this project if they thought that their audience in this case was simply too cool and detached for emotional approaches used by museums such as the International Museum of Slavery in Liverpool or the Jewish Museum in Berlin, which both make use of highly affective designs. The responses differed, often reflecting the "typical visitor" to their museums or the visitor profile they wanted to target with the special exhibition, especially in terms of professional background, political orientation, class, and region.

Some conceded that a certain anti-political correctness and negative attitude vis-à-vis moralizing or emotional approaches to the past often dominates the Danish public discourse, not least when it comes to the colonial past. This group found it necessary to design their exhibitions in ways that were not too explicit in conveying a strong, direct moral message. They argued that it was more effective to invite the audience to reflect on the topics themselves, thereby leaving the conclusion open to the visitor. As one explained:

if you just expose the rude facts and numbers, some visitors will respond with a "that's a lie" or decline it as left-winged rubbish [...] So it's more effective to poke the visitor in a subtler way without pointing fingers directly at him.

Other curators were not afraid of using affective approaches in designs and guided tours and did not agree that the Danish audience in general was more distanced than others. They explained that Western museums historically have created expectations of distance among frequent museum visitors, but also that this expectation can be and is being challenged.

\section{Respecting victims and descendants}

Although not initially afraid of employing affective tools, some curators who advocated for being more provocative ended up with exhibition designs more downplayed than originally intended, particularly after attending some of the curatorial seminars and workshops in the run-up to the centennial. In terms of directly exposing the violence of enslavement, some curators paid particular attention to a talk given by Mary Nicole Elliott, curator at the National Museum of African American History and Culture in Washington, DC, in 
which she explained that there is no way a museum can make the audience truly understand the horrors of the middle passage or life on a plantation. ${ }^{11}$ They also listened to the concerns presented in workshops and mixed-media interventions created by British-Nigerian art historian Temi Odumosu, who was based in Copenhagen. She advocated for a sensitive, careful approach to very loaded historical representations, revealing how racist logics encoded in mutilated or grotesque images of Africans as commodities are perpetuated in the present day (e.g., Odumosu 2016, 2015; Odumosu \& Schroeder 2015). ${ }^{12}$

The curatorial workshops prompted some curators to look for more subtle ways of representing the atrocities - often by featuring text excerpts from eyewitness depictions of punishments or the middle passage rather than visual representations. One curator explained that, inspired by the Jewish Museum in Berlin where visitors walk on abstract steel faces, she initially had envisioned that visitors would similarly walk on faces while passing through a mock-up of a slave ship. During the preparation process, however, the curator changed her mind, fearing that this type of design might be offensive and settled on a subtler expression. Interestingly, the first idea was somewhat similar to that employed in a centennial special exhibition at the Maritime Museum in Flensburg, Germany, ${ }^{13}$ which was guest-curated by Jamaican curator Imani Tafari-Ama. On the floor, human silhouettes painted in white reminded the visitor of both a crime scene but also the silhouettes of enslaved Africans onboard the iconic etching of the slave ship Brookes. Visitors had to walk on the silhouettes to get to the different showcases. The examples attest to the fact that the background of the individual curator often influenced her level of certainty about what would be appropriate.

One way to approach this uncertainty could be to invite stake-holding communities to co-create or respond to the exhibition designs or invite guest curators of African descent to lead the curatorial process as the Maritime Museum in Flensburg did. Several curators visited one or more museums abroad to gain inspiration, such as the International Museum of Slavery in Liverpool, the Museum of London Docklands, the Rijksmuseum in Amsterdam, and the Jewish Museum in Berlin, which have all worked to include minority communities. Examples from the UK show that identifying community representatives has proven extremely complex (Smith et al. 2011). The situation is not qualitatively different in Denmark. However, almost all curators agreed that the international models were not easily transferable to a Danish context. Unlike the UK, the Netherlands, and France, which all have larger African and African-Caribbean communities from former colonies, immigrants, refugees, and adoptees of African descent only make up a small part of the Danish population. Moreover, very few African-Caribbean people from the DWI migrated or were brought to Denmark before and after the transfer in 1917, and do not make up a distinct group. ${ }^{14}$

Some left the matter there. Others operated with a wider definition of stakeholders, which created another problem, namely that most Danes of African descent have no direct ties to the DWI/USVI and do not necessarily represent the 
perspectives of Virgin Islanders. On the other hand, museums focusing exclusively on the binary relationship between Denmark and the Virgin Islands/DWI were criticized for overlooking the problems people of African descent suffered in terms of racism in Denmark. Several curators struggled with these dilemmas. Some chose to invite artists from the USVI ${ }^{15}$ and/or activists of African descent to contribute to the exhibitions. With a single exception, however, none of the curators involved were of African descent.

\section{The Workers Museum (Arbejdermuseet): Stop Slavery!}

Past and present slavery and the resistance to it was the overarching theme chosen by the Workers Museum, curated by historian Rikke Halberg with guest curators from the Danish branch of the Fairtrade Foundation, the NGO Danwatch, and secondary school students, among others. Reflecting the dilemma of whether to choose a specific Danish-Virgin Islands perspective or a broader, more encompassing story, the museum chose to divide the exhibition into two related themes: one dealing with the specific history of slavery in the DWI, the other with contemporary forms of enslavement. Illustrated by a circular exhibition structure, the visitor started and ended in the same room. This was meant to encourage visitors to identify with the past and present victims of slavery. The room was dominated by a huge screen showing images of people of various ages and complexions accompanied by excerpts from Article 4 in the Universal Declaration of Human Rights banning slavery.

The exhibit used several strategies in its effort to sensitively and persuasively represent the violence of slavery. The section "At the Gold Coast" featured excerpts of historic texts describing the horrifying punishment for resistance issued by the administrators in Danish forts. A rolling projection of enslaved Africans' names, including their age, gender, and height, revealed the limited archival evidence available to construct a view of them as individual human beings, but also gave the visitor a glimpse of their humanity-their African names. In the following section "The Danish West Indies 1672-1917," the first list was followed by a second in which the African names were replaced by European names, some of which were highly demeaning, such as "Skidenøje" ("Shitty eye") and "Benrad" ("Skeleton"), attesting to the dehumanization of Africans. The violence became more personalized when the visitor passed through a tunnel representing the middle passage, while listening to a reading from The Interesting Narrative ([1789] 1995) by Olaudah Equiano, in which he describes his experiences of enslavement and the ordeal onboard a slave ship.

The exhibit employed several experiential features meant to disorient the visitor: instead of passing directly to the slave market after passing through the tunnel, the visitor encountered a planter's chair. The chair was one of the most hated objects on the plantations and among the first objects destroyed during revolts. Visitors could sit in it; however, a sign warned of what it means to take that position. The visitor choosing to sit experienced an embodied, highly 
gendered, power pose with legs elevated and spread. At the same time, the visitor was surrounded by documents in the exhibition space depicting how enslaved Africans used plants to poison plantation overseers and a work of art on that very topic, Maroon Mountain. ${ }^{16}$ Also, the chair looked directly back at a photograph of a contemporary African mine-worker. This linked past and present, provoking the visitor to reflect on contemporary labor conditions of miners for rare minerals in Africa, used in commodities that are treasured as much by the affluent parts of today's world as colonial commodities were in the 17 th and 18 th centuries.

The specific Virgin Islands-Danish history ended in 1917 and was followed by a room dedicated to forms of modern-day slavery. According to the curator, many react with skepticism when presented with the fact that an estimated 40 million people live in contemporary forms of slavery. ${ }^{17}$ For this reason, the section documented contemporary slavery with facts, figures, and documentation, appealing to the logos, rather than the pathos, of the audience. Different panels motivating the audience to act accompanied the documentation. Finally, the museum invited NGOs working on related issues to guest curate a corner of this room on a rolling basis. When I visited, the Fairtrade Foundation had decorated the corner with purses hanging from the ceiling encouraging visitors to use their power as consumers. Another panel encourages visitors to visit the website http://slaveryfootprint.org, where details of consumer habits give an approximation of how many people living under slavery have probably produced those everyday goods.

\section{The Royal Library (Det Kgl. Bibliotek): Blind Spots-images of the Danish West Indies Colony}

Drawing on its vast collection of visual material from the DWI, this exhibition curated by art historians Mette Kia Krabbe, Mathias Danbolt, and research librarian Sarah Giersing, with sound-installations by art historian Temi Odumosu, aimed to sensitize the audience to the hidden power structures and racial stereotypes guiding historical and contemporary visual representations of the DWI/USVI. Exhibited items included historic maps, engravings, books, paintings, porcelain, family albums, and postcards, as well as recent artworks by Danish-Caribbean artist Jeanette Ehlers, St. Croix artist La Vaughn Belle, and Danish artist Nanna Debois Buhl. The exhibition followed a strict chronological structure starting with the early colonization of the islands and ending in the 21st century, with discussions on the lingering effects of racism and colonial nostalgia in contemporary visual material.

The exhibition employed several strategies to represent the violence of slavery in a respectful way and bring in input from representatives of the diaspora and descendants of the enslaved. A video documentation of Ehlers' performance "Whip it good," in which the artist comments on colonial amnesia by lashing a white canvas with a whip immersed in charcoal, dominated the room 
dedicated to enslavement titled "The Unfree Bodies of Colonial Life."18 The room's only direct visual representation of violence on an enslaved body was an engraving by William Blake depicting an African woman hanging by her hands from a tree. The picture is from 1793 and was published in the Dutch-British colonial soldier John Gabriel Stedman's eyewitness account (1796), and the image was displayed next to the engraving, opened to a page describing terrifying scenes of punishment the author witnessed in the Dutch colony Suriname. Moreover, this room and two others in the exhibition feature counter-archival artworks by Belle inspired by, among other events, the resistance of St. Croix workers to unjust working conditions during the Fireburn in $1878 .^{19}$

In collaboration with the special exhibition at the National Gallery, the Royal Library invited Temi Odumosu to intervene in parts of their exhibitions with alternative perspectives, resulting in the participatory soundproject What Lies Unspoken. ${ }^{20}$ The intervention was based on a series of workshops with activists, artists, scholars, and students, who were invited to respond and comment on artifacts in the National Gallery and the Royal Library. The recorded discussions were edited into a soundscape accompanying the artifacts exhibited. The project simultaneously aimed at providing new and alternative readings to an audience with a pre-established knowledge of the works in question, but also to create openings to representations of colonial imagery stemming from distant times that often appear enigmatic to modern-day viewers. ${ }^{21}$

The exhibition concluded with a section titled "After Images" on present-day manifestations of neo-colonial imagery and racial stereotypes, namely a Danish video game on the slave trade and nostalgic exoticism in advertisements for "the Danish West Indies" by the Danish tourist industry (also see Andersen 2013b). ${ }^{22}$ The video game "Playing History: The Slave Trade," produced as an educational game, caused international furor a few years back. Commentators were offended by black-faced figures and a scene where the player loads a ship with Africans in a Tetris game. ${ }^{23}$ Projected onto two large canvases, Danish-African actor Anna Neye discusses the game with a game designer, who explains that his team members designed the dolls mimicking a well-established tradition of Danish TV-dolls. ${ }^{24}$ Blackfacing also has a history in Denmark, ${ }^{25}$ but the team reportedly did not realize what the dolls ended up looking like to people who know this phenomenon all too well. This fact again reflects the broader ignorance in Danish society of words, visual styles, and behavior that is offensive to people of African descent.

This exhibition did not include features that motivated the visitor to take direct action, but rather served as a reminder to the visitor of how different people approach the colonial past, aiming at creating a new awareness in the visitor that could potentially hinder repetitions of similar forms of oppression. 


\section{The Maritime Museum: Vestindien Revisited}

While most of the other special centennial exhibitions primarily focused on the period before 1917, the exhibition at the Maritime Museum in Elsinore, curated by anthropologist Nathalia Brichet, artist Camilla Nørgaard, and head-ofexhibition Marie Ørstedholm, concentrated on the period after 1917, zooming in on St. Thomas harbor and the physical traces of Danish colonialism today. Guided by the idea that to be colonized then and now is (also) to be subjected to dreams and plans dreamt up elsewhere, the exhibition juxtaposed the glossy images of the tourist paradise (as the islands are branded) with tourism's detrimental socioeconomic and environmental side-effects. The exhibition was based on fieldwork among different stakeholders in St. Thomas harbor. Consequently, it paid close attention to a story that figures prominently in local St. Thomas narratives on Danish colonialism but is rarely mentioned in Danish accounts of the history. This account emphasizes how Danish enterprises, driven by a mix of commercial interests and patriotism, negotiated certain advantages in relation to the treaty of the transfer that prolonged the Danish colonial infrastructure up until 1993. It was only then that the Danish-owned company WICO, which owned the major part of the harbor, after years of local discontent was finally bought by the local government. Moreover, the cruise-ship industry was to a large extent developed by the former Danish company, who profited greatly from the growing industry (Hansen 2016).

Tacitly pointing to the concept of dark tourism, which usually refers to tourist excursions to sites of danger, mass violence, or catastrophe, the curators were inspired by Anthropocene theory and interpreted the harbor as a landscape destroyed by people. Simultaneously, the fragile economy of the islands is almost entirely dependent on mass tourism, which was part of the reason the curators felt they had to proceed carefully with a one-sided critique. However, to emphasize the downside of this industry, the exhibition employed a raw and unfinished aesthetic with plywood showcases and exhibited discarded items they had collected such as sunglasses, flip-flops, straws, sun lotion, and towels forgotten by tourists at local beaches and dead corals. The tourist images of crystalclear water, wedding photos, white beaches, and tax-free diamonds were juxtaposed with plastic bags turned into "gems" by Nørgaard. Signs explained how chemicals such as tributyltin, used in paint for boats, and oxybenzone, used in sunscreen, have devastating effects on the local marine ecosystems.

The focus on environmental destruction and preoccupation with scrap was thus created to surprise, disorient, and provoke visitors with a pre-established, often positive, if not vested interest in the maritime sector and holiday aspects of the USVI - as the typical visitor profile of the museum includes stakeholders in the Danish maritime industry. They were asked to reconsider the problematic side of this industry and its Danish roots. The guiding texts were very short, leaving a lot of analytical work to the visitor, but the museum also produced a booklet with more thorough explanations sold at a low price (Brichet et al. 2017). 


\section{Did the museums move the audience?}

"Are we preaching for the already converted?" asked Jamaican guest-curator Imani Tafari-Ama from the Maritime Museum in Flensburg during a seminar in Copenhagen, ${ }^{26}$ raising a question also dealt with in this volume: did the museums effectively persuade their audience?

As the editors of this volume point out, visitors are "emancipated spectators" and "the effect of the sites' pathos is open to reinterpretation by visitors" (p. 9). The few visitor responses I have sampled are anecdotal and not conclusive. A general pattern among visitors based on observation and conversations was that visitors without much prior knowledge of the topic and teachers taking students on museum visits preferred exhibitions with a broad, chronological, and book-like approach. Some from this group also found exhibitions focusing in on a single aspect of the colonial history harder to follow and exhibitions featuring many artworks distracting. Visitors who already had a solid knowledge of the subject and its problematics reacted more favorably to this kind of intervention, although they differed on which exhibitions they preferred. The hesitancy to expose the public more directly to the violence of slavery was sometimes a point of critique. Moreover, while having ambitions to portray West Indians/ Virgin Islanders in nuanced ways, some exhibitions ended up portraying both historic and living Danes as rather one-dimensional, which made some visitors reject the exhibition as un-nuanced. Virgin Islanders also reacted differently to the same exhibitions. One group of Virgin Islanders commended the Maritime Museum for telling an often-hidden aspect of the history of St. Thomas, while other Virgin Islanders found it problematic, in part because it did not deal with race and positionality, but also because it overlooked the positive role the beaches also play in local narratives of the Virgin Island cultural history.

Because there were nearly 30 programmed special exhibitions, each museum had to carve out a very specific approach. The fact that many exhibitions supplemented each other allowed the audience to view them as an unintentional Gesamtwerk offering a variety of approaches to the same past. It is unclear, however, how many visitors visited more than one or two exhibitions.

Some curators reported that in their guided tours they used affective approaches, highlighting the traumatic dimensions of the topic, and received positive visitor responses, attesting both to the fact that not all visitors were "too cool" to this type of approach and that the message taken home by visitors is influenced by more than the exhibition design. Much depended on the background of the individual visitors, the number and type of museum(s) they visited, and how they visited and related what they saw to the massive media coverage of the event in 2017. Hence, the impact of a single museum on public interpretations is difficult to pinpoint.

However, several museums reported an unusually high number of visitors, including many school groups, suggesting that the museums undoubtedly contributed to raising the general level of awareness of the colonial past in 
Denmark. Compared to the previous neglect of this history in Danish museums, the 2017 special exhibitions in this regard represented a major leap forward.

It remains an open question if the new insights into curating colonial history gained by some curators and museums during 2017 will have a lasting impact on museum practices in relation to the Danish colonial past. So much depended on individual curators and how they-and their directors-experienced the process. As noted, curators were divided on several key curatorial questions, especially in terms of affect and the inclusion of non-curators. Some curators became keen to employ their new insights into other related projects, while others stated that it had been much too stressful and the personal consequences too high. Additionally, Danish museums have been forced to cut back on staff because of annual state reductions to culture and research, so it is also uncertain if the curators involved will be available to take on new projects again. 2020 marks the 400th anniversary of Danish colonialism in India and 2021 the 300th in Greenland. It will be interesting to follow how the 2017 experiences will be translated into these upcoming centennials.

\section{Notes}

1 This work forms part of the ECHOES project, which has received funding from the European Union's Horizon 2020 research and innovation program under grant agreement No. 770248.

2 The islands were sold to the US in 1916 and possession was transferred in 1917; hence, March 31 has since been marked as "Transfer Day" in the USVI. The word has no Danish equivalent. On the ambivalent meaning of this event to USVI local identity and memory cultures see Bastian (2003).

3 The exhibitions were hosted by The National Gallery, The Royal Library, Horsens Prison Museum, Vejle Museum, The Workers Museum, the Maritime Museum, Christiansborg Palace, The Police Museum, Vestsjellands Museum, Øregaard, Odrupgaard, Gl. Holtegaard, Frilandsmuseet, and The Women's Museum. Smaller museums included Humlemagasinet, Museum Mors, Assistens Churchyard, Kongeåmuseet, Danmarks Sukkermuseum i Nakskov, Samsø Museum, Svendborg Museum, and Flynderupgård. Small exhibitions were also hosted by Borreby Gods, Sølyst, Ballerup Library, Copenhagen Town Hall, Rudersdal libraries, The State Archives and the pop-up museum and cultural centre Den Vestindiske Kulturambassade, the Gallery meter, and the Gallery SixtyEight Art Institute. A small traveling exhibition created by the Danish West Indian Association was hosted by several public schools and libraries throughout the country.

4 “Dangerous Forts," The National Museum of Denmark September-October 2010.

5 http://den-vestindiske-arv.dk/en/the-project-and-the-website.

6 Notably "Curatorial Challenges," Copenhagen University, May 26-27, 2016; "Troublesome Pictures Representing the Colonial Past," Gentofte, June 2, 2016; "Representing History through Data: Datasprint series," October 10, November 12, December 10, 2016; “Workshop Nordic Connections 2017," December 7, 2016, Copenhagen.

7 See, e.g., "DF kalder det 'dumt' at fjerne ordet 'neger' fra værker på Statens Museum for Kunst," Politiken, June 7, 2017.

8 Also see http://pov.international/de-sorte-dukker-fra-vestsjaelland.

9 I took part in this intervention. 
10 "National brugerundersøgelse på de statslige og statsanerkendte museer i Danmark2009", Kulturarvsstyrelsen April 19, 2010.

11 Elliott, Mary Nicole: "Presenting the Story of Slavery and Freedom in the National Museum." Talk given at Workshop Nordic Connections December 7, 2017, 2016, Copenhagen. I was not present. The indirect quotation is formulated from curators interviewed for this project.

12 Also see http://todu1.theimageofblack.com/projects.

13 Up until 1864, the city of Flensburg was part of the Danish colonial trade system. The Maritime Museum in Flensburg thus also decided to commemorate the centennial.

14 Danish censuses make use of the category "country of origin" and distinguish between "immigrants" and "descendants" but do not use the category "race." US Virgin Islanders of African descent thus fall under the category "from the US," while descendants of Danish West Indians register as Danes. This is also the case for other European citizens of African descent.

15 This was the case for Vestsjællands Museum, the Royal Library, Gl. Holtegaard, Christiansborg Palace, and Gallery meter. Also see www.lavaughnbelle.com/news. Vestindisk Kulturambassade hosted the exhibition "Invisible Heritage" featuring USVI artists including David Berg, Janet Cook-Rutnik, Edgar Endress, Jon Euwema, and Gerville Larsen.

$16 \mathrm{http}: / /$ nannadeboisbuhl.net/maroon.

17 According to recent research developed jointly by the International Labour Organization and the Walk Free Foundation, in partnership with the International Organization for Migration. www.ilo.org/global/about-the-ilo/newsroom/news/ WCMS_574717/lang-en/index.htm, visited March 22, 2018.

18 www.jeannetteehlers.dk.

19 The works are from the series Chaney, Cuts and Burns, and the Photomontage Series, www.lavaughnbelle.com/\#/infinite.

20 http://livingarchives.mah.se.

21 I participated in the workshop used in the sound installation at the National Gallery.

22 I took part in this installation.

23 www.playinghistory.eu. The tetris feature was later removed.

24 The dolls mimic TV productions such as Jullerup Færgeby (1974) and Vinterby Øster (1973).

25 The popular comedy "Styrmand Karlsen" from 1958 filmed partly at former Danish colonial forts in Ghana is an example of this.

26 Lecture by Dr. Imani Tafari-Ama. Den Vestindiske Kulturambassade. February 25, 2017.

\section{References}

Andersen, Astrid Nonbo. 2013a. Islands of Regret—Restitution, Connected Memories and the Politics of History in Denmark and the US Virgin Islands. University of Aarhus: Unpublished Ph.D. Dissertation.

Andersen, Astrid Nonbo. 2013b. “'We Have Reconquered the Islands': Figurations in Public Memories of Slavery and Colonialism in Denmark 1948-2012." International Journal of Politics, Culture and Society, 26.1: 57-76.

Andersen, Astrid Nonbo. 2014. "Between Patriotism and Regret: Public Discourses on Colonial History in Denmark Today." In Fihl, E. \& A.R. Venkatachalapathy (eds.) Beyond Tranquebar: Grappling Across Cultural Borders in South India. Hyderabad: Orient BlackSwan.

Andersen, Astrid Nonbo. 2017. Ingen undskyldning-Erindringer om Dansk Vestindien og kravet om erstatninger for slaveriet. København: Gyldendal. 
Andersen, Astrid Nonbo \& Thisted, Kirsten. "Whatever a colony is: 1945-1953 as a zero hour in Danish-Greenlandic relations", in Schulz-Forberg, Hagen (ed.), Zero Hours. Politics of Time in Global Perspectives, 1940s-1970s, Palgrave Macmillan, London. (forthcoming).

Andersen, Astrid Nonbo. 2018. "The Reparations Movement in the United States Virgin Islands." The Journal of African American History 103(2): 104-132.

Barkan, Elazar. 2000. The Guilt of Nations-Restitution and Negotiating Historical Injustices. Baltimore, MD and London: The Johns Hopkins University Press.

Barringer, T., \& Flynn, T. (eds.) 1998. Colonialism and the Object: Empire, Material Culture and the Museum. London: Routledge.

Bastian, Jeannette Allis. 2003. Owning Memory—How a Caribbean Community Lost Its Archives and Found Its History. London: Libraries Unlimited.

Brichet, N., Nørgaard, C., \& Ørstedholm, M. 2017. Vestindien Revisited—I kolvandet på kuldampere og cruiseturister. Helsingør: M/S Museet for Søfart.

Brichet, Nathalia. 2017. Awkward Encounters in Heritage Work. An Anthropology of Common Ground. Manchester: Mattering Press.

Equiano, Olaudah. [1789] 1995. The Interesting Narrative of the Life of Olaudah Equiano. Boston, MA: Bedford Books of St. Martin's Press.

Halberg, Rikke Lie. 2016. Dansk Vestindien på museum Kontinuitet og brud i udstillingspraksis 1888-2013. Master's thesis. University of Lund.

Hansen, Pernille Østergaard. 2016. Our Tropical Home: Danish "Empire Migrants" in the U.S. Virgin Islands, 1917-1945. Unpublished Ph.D. dissertation, Florence: European University Institute.

Kaplan, C., \& Oldfield, J. 2010b. Imagining Transatlantic Slavery. London: Palgrave Macmillan..

Karp, I., Kratz, C. A., Szwaja, L., \& Ybarra-Frausto, T. 2006. Museum Frictions: Public Cultures/Global Transformations. Durham, NC: Duke University Press.

Lehrer, Erica, \& Milton, Cynthia E. 2011. "Introduction: Witnesses to Witnessing." In Erica Lehrer, Cynthia E. Milton, \& Monica Patterson (eds.) Curating Difficult Knowledge: Violent Pasts in Public Places. London: Palgrave Macmillan.

Linenthal, Edward. 1995. Preserving Memory: The Struggle to Create America's Holocaust Museum. New York: Viking USA.

Nielsen, Vibe. 2017. "Museale formidlinger af fortiden som kolonimagt på danske og britiske museer." Slagmark, 75: 81-94.

Odumosu, Temi. 2015. "Blind Spots (A Traveller's Tale): Notes on Cultural Citizenship, Power, Recognition and Diversity." Museums-Citizens and Sustainable Solutions. Danish Agency for Culture: 110-119.

Odumosu, Temi. 2016. "Rude Encounters: The 'Jolly Nigger Bank' as a Visual Problem from America to Denmark." In Stocker, Mark, \& Phillip Lindley (eds.) Tributes to Jean Michel Massing: Towards a Global Art History. Turnhout: Harvey Miller Publishers.

Odumosu, Temi, \& Hannes Schroeder. 2015. "Memorializing Contested Landscapes." Journal of African Diaspora Archaeology and Heritage, 4.3: 189-194.

Olwig, Karen. 2003. "Narrating Deglobalization: Danish Perceptions of a Lost Empire." Global Networks, 3.3: 207-222.

Ranciere, Jacques. 2009. The Emancipated Spectator. London, UK/Brooklyn, NY: Verso.

Smith, L., Cubitt, G., Wilson, R., \& Fouseki, K. 2011. Representing Enslavement and Abolition in Museums. New York \& London: Routledge. 
Stedman, John Gabriel. 1796. Narrative of a Five Years' Expedition against the Revolted Slaves of Surinam: In Guiana, on the Wild Coast of South America; from the Year 1772, to 1777. London: J. Johnson, \& J. Edwards.

Wilson, Ross. 2011. "The Curatorial Complex: Marking the Bicentenary of the Abolition of the Slave Trade." In Smith, L., et al. (eds.) Representing Enslavement and Abolition in Museums. New York \& London: Routledge. 